\title{
Intravenous ondansetron induced hypersensitivity reaction: a case report
}

\author{
S. Nitya, M. Shanthi*, R. Meenakshi, S. Kiruthika
}

Department of Pharmacology, Sri Manakula Vinayagar Medical College and Hospital, Pondicherry, India

Received: 15 March 2021

Accepted: 12 April 2021

*Correspondence:

Dr. M. Shanthi,

Email: shanthibabu24@gmail.com

Copyright: () the author(s), publisher and licensee Medip Academy. This is an open-access article distributed under the terms of the Creative Commons Attribution Non-Commercial License, which permits unrestricted non-commercial use, distribution, and reproduction in any medium, provided the original work is properly cited.

\begin{abstract}
Ondansetron a selective 5- $\mathrm{HT}_{3}$ receptor antagonist has been widely used as a prophylactic antiemetic for chemotherapy induced and anaesthesia related nausea and vomiting. Anaphylaxis and anaphylactoid reaction rarely occur in less than $1 \%$ of the patients and may lead to potentially life-threatening events. This study is one such rare case report of hypersensitivity reaction to intravenous ondansetron in a perioperative setting. Familiarity about anaphylactoid reactions to intravenous ondansetron among the health practitioners would help them to bring about a rational approach to decrease its incidence.
\end{abstract}

Keywords: Ondansetron, Adverse drug reaction, Intravenous, Hypersensitivity

\section{INTRODUCTION}

Ondansetron a selective 5-hydroxytryptamne-3 (5- $\left.\mathrm{HT}_{3}\right)$ receptor antagonist has been widely used as a prophylactic antiemetic for chemotherapy induced and anaesthesia related nausea and vomiting. ${ }^{1}$ The most common adverse effects seen with use of ondansetron are headache, fatigue, malaise and constipation. ${ }^{2}$ Anaphylaxis and anaphylactoid reaction rarely occur in less than $1 \%$ of the patients. This study is one such rare case report of hypersensitivity reaction to intravenous ondansetron.

\section{CASE REPORT}

A 30 year old female patient diagnosed with retained products of conception following medical termination of pregnancy done one week earlier and was posted for dilatation and curettage under anaesthesia. Patient was administered with a single intravenous injection of ondansetron $4 \mathrm{mg}$ following which maculopapular rash was observed near the intravenous cannula site on the left forearm. Immediate intravenous dexamethasone $4 \mathrm{mg}$ and chlorpheniramine maleate $20 \mathrm{mg}$ were given after which the rash subsided within minutes. The patient had no history of similar reaction in the past to ondansetron. The adverse drug reaction was moderate in nature given by the severity assessment using Hartwig's severity assessment. Further, Naranjo's algorithm suggested a probable casualty (total score $=6$ ).

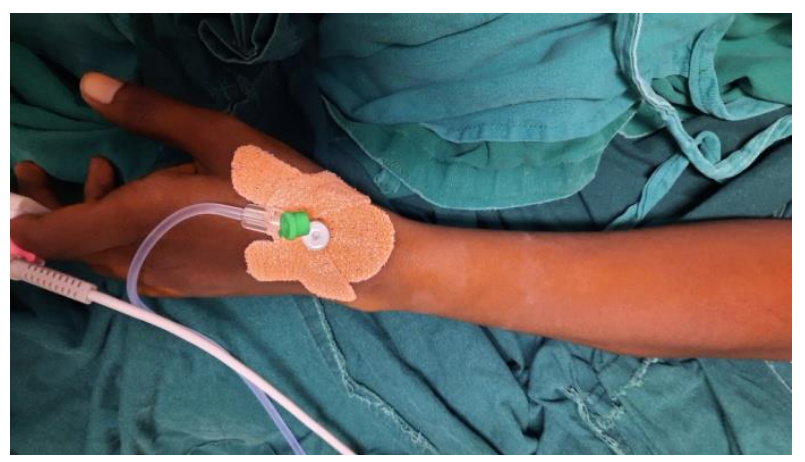

Figure 1: Intravenous administration of ondansetron. 


\section{DISCUSSION}

Anaphylactoid reactions involve non IgE mediated histamine release or by activation of complement system. It produces symptoms and signs similar to that of anaphylaxis. Incidence of anaphylactoid reactions are seen with colloids, iodinated contrast agents, drugs such as neuromuscular blockers, antibiotics and opioids. ${ }^{3}$ Ondansetron is listed under the WHO essential drugs for its safe and effective antiemetic property and is being widely used for chemotherapy and anaesthesia related nausea and vomiting. Frequently reported side effects are constipation, dizziness and headache and certain cardiac arrhythmias. $^{2}$ However, anaphylactoid reactions with antiemetics especially with ondansetron have been reported, albeit rarely, with the most common presentation were being cutaneous rashes. ${ }^{4-6}$ Both IgEmediated and non-IgE-mediated hypersensitivity reaction can occur with ondansetron. However, nonimmunologic induction of maculopapular rash can also occur by direct mast-cell degranulation without IgE-mediated chain reaction. ${ }^{7}$ Clinicians must be aware of such potential adverse events.

\section{CONCLUSION}

Anaphylactoid reactions during the perioperative period are often rare and may also be life-threatening. However, there is paucity in the reporting of these reactions. Familiarity about anaphylactoid reactions to intravenous ondansetron among the health practitioners would help them to bring about a rational approach to decrease its incidence.

\section{Funding: No funding sources}

Conflict of interest: None declared

Ethical approval: Not required

\section{REFERENCES}

1. Ye JH, Ponnudurai R, Schaefer R. Ondansetron: a selective 5-HT(3) receptor antagonist and its applications in CNS-related disorders. CNS Drug Rev. 2001;7(2):199-213.

2. Smith RN. Safety of ondansetron. Eur J Cancer Clin Oncol. 1989;25(1):S47-50.

3. Lagopoulos V, Gigi E. Anaphylactic and anaphylactoid reactions during the perioperative period. Hippokratia. 2011;15:138.

4. Ross AK, Ferrero-Conover D. Anaphylactoid reaction due to the administration of ondansetron in a pediatric neurosurgical patient. Anesth Analg. 1998;87:779-80

5. Chen M, Tanner A, Gallo-Torres H. Anaphylactoidanaphylactic reactions associated with ondansetron. Ann Intern Med. 1993;119(8):862.

6. Kossey JL, Kwok KK. Anaphylactoid reactions associated with ondansetron. Ann Pharmacother. 1994;28(9):1029-30.

7. Bernstein IL, Li JT, Bernstein DI, Hamilton R, Spector SL, Tan R, et al. Allergy diagnostic testing: an updated practice parameter. Ann Allergy Asthma Immunol. 2008;100:S1-148.

Cite this article as: Nitya $S$, Shanthi M, Meenakshi $\mathrm{R}$, Kiruthika S. Intravenous ondansetron induced hypersensitivity reaction: a case report. Int J Basic Clin Pharmacol 2021;10:578-9. 